\title{
THE STATE OF GLOBAL SCIENTIFIC LITERATURE ON CHLOROPHYLL-A
}

\section{O ESTADO DA ARTE DA LITERATURA CIENTÍFICA GLOBAL SOBRE CLOROFILA-A}

\author{
Suzana Maria Loures de Oliveira MARCIONILIO ${ }^{1}$; Maria Tereza Ribeiro ALVES ${ }^{1}$; \\ Pedro Paulino BORGES ${ }^{1}$; Karine Borges MACHADO ${ }^{1}$; Cleide Sandra Tavares ARAÚJO'; \\ Hélida Ferreira da CUNHA ${ }^{1}$; João Carlos NABOUT ${ }^{1}$ \\ 1. Universidade Estadual de Goiás, Campus Ciências Exatas e Tecnológicas (CCET), Anápolis, GO, Brasil. joao.nabout@ueg.br
}

\begin{abstract}
Chlorophyll is a green pigment common to all photosynthetic cells of autotrophic organisms in aquatic or terrestrial environments. Techniques used to quantify this pigment include fluorescence, UV spectrophotometer, chromatography, HPLC, and remote sensing. Determination of the photosynthetic pigment chlorophyll - a (Chl-a), has been used widely in many areas of science. The present study investigated the state of the global scientific literature on Chl-a, determining the countries, approaches, and environments where Chl-a has been studied and the geographic scale used. To obtain this scientometric information, we conducted a study from the Scopus database over a 21-year period from 1990 through 2011. This period saw significant increases in the number of publications $(\mathrm{r}=0.84$ and $P<0.001)$, different journals where publications appeared (160 journals), major papers with a multidisciplinary character, and a predominance of descriptive approaches with studies conducted in aquatic and marine habitats at a regional scale. The country with the highest number of publications was China (21.64\% of total papers; location of study), and the USA had the highest number of authors (19.52\% of total papers). The main determining factor for publications was socioeconomic (according to model selection criteria; AIC). This study highlight the multidisciplinary use of Chl-a, and may give some directions to new studies about this pigment.
\end{abstract}

KEYWORDS: Photosynthetic pigment. Scientometrics. Water. Phytoplankton biomass.

\section{INTRODUCTION}

The term chlorophyll (Chl-a) was proposed by Pelletier and Caventou (1818) to describe the green substance that can be extracted from leaves with the assistance of organic solvents (LLOYD; TUCKER, 1988). The Chl-a pigment captures photons (pigment-antenna), and is present in all living things that perform oxygenic photosynthesis (BJORN et al., 2009). Quantification of Chl-a has been used as a tool in various fields of knowledge, including bioenergy (SKJANES et al., 2007), biotechnology (KOZIOL et al., 2007), botany (THOMAS et al., 2001), ecotoxicology (PEREZ et al., 2008; SUBASHCHANDRABOSE et al., 2011; RIANO et al., 2012), marine ecology (HAWES et al., 2012; THOMAS et al., 2001), limnology (WETZEL, 2001; HUO et al., 2012), remote sensing (NOVOA et al., 2011; GURLIN et al., 2011) and agriculture (KRAUSE et al., 2010; ZHANG et al., 2010; FERNANDEZ-JARAMILLO et al., 2012).

Chl-a is present in both aquatic and terrestrial environments is used in various areas of science as the control variable. As this study proposed an outline of Chl-a in global research by scientometric, in order to identify research interests with this variable. Scientometric techniques can be used to quantify scientific production and the types of studies in a certain area (MACIAS-CHAPULA, 1998; VANTI, 2002). Scientometric have been used to diagnose trends in scientific literature on, for instance, ecology (PINTO et al., 2003; BINI et al., 2005; FAZEY et al., 2005; MELO et al., 2006), global climate change (STANHILL, 2001; NABOUT et al., 2012), groups of organisms (CARNEIRO et al., 2008; PADIAL et al., 2008; NABOUT et al., 2010), genetics (QUIXABEIRA et al., 2010) bioproducts (e.g. Biodiesel; FERREIRA et al., 2014).

The present study assessed research on Chla over a 21-year period (1990-2011), with the intention of answering the following questions: i) What is the temporal trend in the number of studies on Chl-a? ii) Studies on Chl-a are carried out on what scales, which journals and in which environments? iv) In which countries and regions are these studies performed? v) What factors determine the scientific production of countries where publications on Chl-a appear? In the other word determine the influence of Gross Domestic Product (GPD), Human Development Index (HDI), demographic density, water availability and consumption of fertilizers, in scientific production of nations.

All the information systematized how is the use of variable Chl-a makes it feasible to analyze the results of this work as a step prior study involving the same from the perspective of having jobs that seek to supply necessary research that have not been investigated with referent study variable. 


\section{MATERIAL AND METHODS}

\section{Sampling and quantification of scientific literature}

The literature utilized in this study was obtained from the Scopus database (www.scopus.com), accessed in March 2012. We used the search terms "Chlorophyll a" OR "Chl-a" OR "Chlorophyll-a" OR "Chl a" in the titles of papers that appeared from 1990 through 2011. For each article we determined i) the year of study; ii) the journal; iii) the geographic scale (local, regional, continental or global); iv) the approach used (theoretical, experimental or descriptive); v) the region or country of the study and the country of the first author (nationality); vi) the type of environment (terrestrial, marine or continental).

With respect to the approach (item IV), the term "experimental" was used for articles that used a Chl-a variable to develop laboratory techniques such as synthesis reactions, reaction kinetics, and characterization of the physicochemical properties of Chl-a, among others. Theoretical studies, in general, included revisions. Finally, descriptive studies were considered as those involving field research and/or quantification of Chl-a in the laboratory.

\section{Data analysis}

The temporal trends of number of papers were investigated using a Pearson correlation $(\mathrm{P}<0.05)$ to relate the number of articles to the year when they were published. To investigate the determining factors for the scientific production of countries (i.e., numbers of papers by country where the study took place) several models were constructed. These models were compared using the Akaike Information Criterion (AIC) (BURNHAM; ANDERSON, 2002), in which the best model was the one that gave the lowest value of AIC. These analyses included specific countries only; papers that merely indicated the study region, such as Africa or the Atlantic Ocean, were not included in the analyses.

In the models, the number of papers for countries was regressed as a function of five explanatory variables: Gross Domestic Product (GDP, in dollars, obtained from the International Monetary Fund for the year 2011), Human Development Index (HDI, obtained on the website of the United Nations Development program UNDP, for the year 2011), demographic density
MARCIONILIO, S. M. L. O. et al.

(inhab/ $\mathrm{km}^{2}$ ), water availability $\left(\mathrm{m}^{3}\right)$ and fertilizer consumption (hundreds of $\mathrm{mg} \mathrm{ha}^{-1}$; UNDP website, accessed in September 2012). Using this set of variables, 31 different models were generated and then compared according to the selection criteria of AIC models.

The importance of these factors is summarized in the fact that scientific research is a reflection of socioeconomic and environmental factors, but tested whether these studies reflect the Chl-a in different countries through the analysis of the regression model. It is expected that countries with greater water availability, fertilizer consumption and GDP may be those who develop more work on this variable. The analysis was performed using the software SAM 4.0 (RANGEL et al., 2010).

\section{RESULTS}

Between 1990 and 2011, 2175 articles appeared that refer to studies on Chl-a. The number of articles on this subject has increased significantly along the period of the study ( $\mathrm{r}=0.84$ and $P<0.001$ ) (Figure 1). We found 160 journals that published articles on Chl-a. Of these, only 20 journals published $44.01 \%$ of the total (Figure 2). We classified 2031 papers as descriptive, experimental or theoretical. Most studies were descriptive (1144 papers, or $53 \%$ of the total articles studies), followed by experimental (703 papers, $32.6 \%$ ) and theoretical studies (184 papers, 8.5\%). Some paper were not classified, according type of studied (descriptive, experimental and theoretical) (5.9\%). Regarding geographic scale, $51.6 \%$ of publications on Chl-a were regional, $37.8 \%$ local, and $10.5 \%$ continental or global. We classified 1431 papers as the type of environment studied (terrestrial, marine or continental). The marine environment was more studied, with $37.8 \%$ of the papers (540 papers); while continental waters represented $25.7 \%$ (369), and terrestrial environments $36.5 \%$ (522).

Regarding the nationality of the first authors, most publications were from the United States of America (USA) with $19.52 \%$ (421 papers), followed by China with $13.86 \%$ (299) and Japan with $11.21 \%$ (242). However, considering the area of study, the largest number of studies were conducted in China with $8.22 \%$ (179), followed by the USA with $3.72 \%$ (81) and Japan with $1.88 \%$ (41) (Figure 3). 


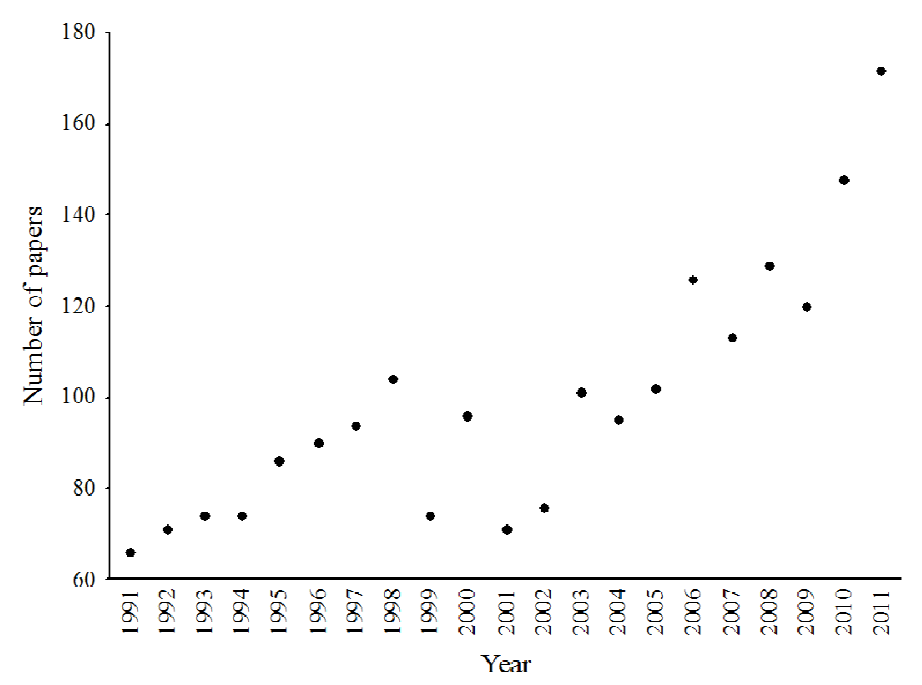

Figure 1. Temporal trend in the number of articles published per year in the period 1990 to 2011.

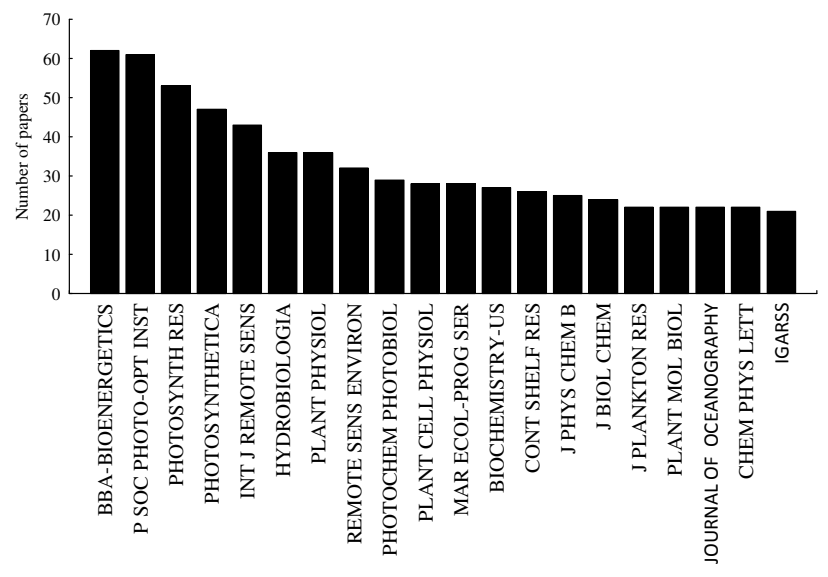

Figure 2. The principal journals where publications on chlorophyll-a have appeared.

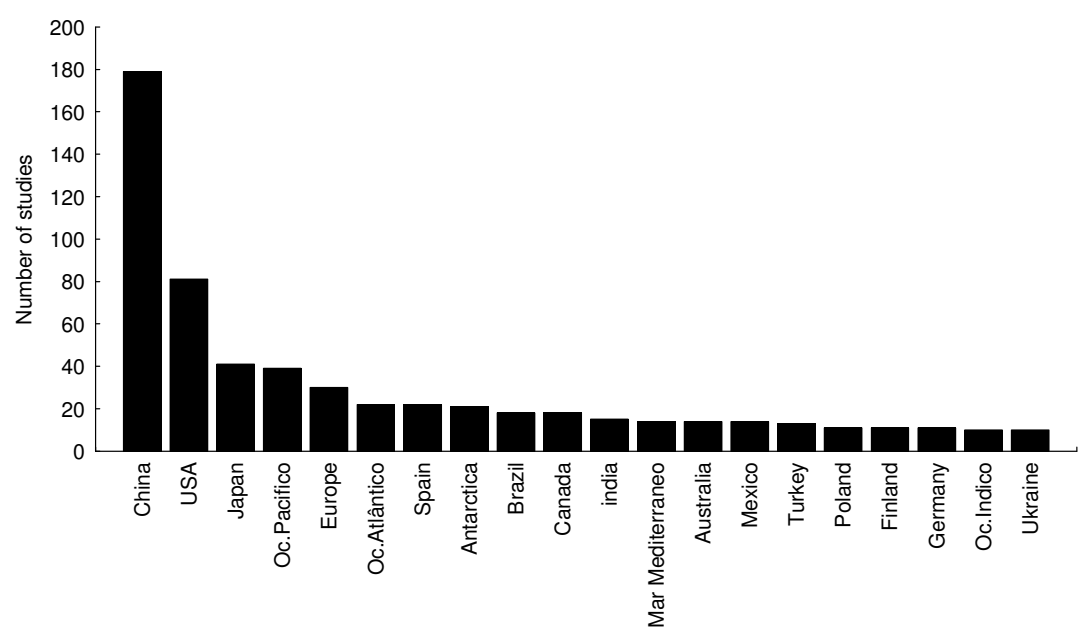

Figure 3. Countries or regions where studies were performed on chlorophyll-a.

Five of the AIC models were classified as top models $(\mathrm{AIC}<2)$. In these models, all variables were present. The best model was composed exclusively by GDP and explained $66 \%$ of the variation in countries where publications appeared (Table 1). The GPD was present in all top models and presented positive relation with the number of papers published by different countries (Table 2); in other words, countries with a larger number of publications on within-country study areas were those with the higher GDPs, supporting the hypotheses suggested here. Another supporting 
variable was water availability, i.e., countries with more publications are those with more water availability (Table 2). In contrast, the scientific production by country was negatively related to demographic density, fertilizer consumption and HDI.

Table 1. Results of the 31 models generated to identify the socio-economic factor that best explains the study region with chlorophyll-a. The variables are population density (inhabitants / km 2) (D); GPD (millions of dollars), water availability (W); fertilizer consumption (F), HDI.

\begin{tabular}{|c|c|c|c|}
\hline Variables & $\mathrm{R}^{2}$ & AIC & Delta AIC \\
\hline GPD & 0.662 & 10.537 & 0 \\
\hline GPD, HDI & 0.669 & 11.813 & 1.275 \\
\hline GPD, F & 0.667 & 12.129 & 1.592 \\
\hline $\mathrm{D}, \mathrm{GPD}$ & 0.666 & 12.206 & 1.668 \\
\hline GPD, W & 0.666 & 12.241 & 1.703 \\
\hline D, GPD, HDI & 0.677 & 12.933 & 2.396 \\
\hline GPD, W, HDI & 0.676 & 12.975 & 2.437 \\
\hline GPD, W, F & 0.672 & 13.775 & 3.237 \\
\hline $\mathrm{D}, \mathrm{GPD}, \mathrm{F}$ & 0.67 & 13.979 & 3.442 \\
\hline GPD, F, HDI & 0.67 & 14.083 & 3.546 \\
\hline $\mathrm{D}, \mathrm{GPD}, \mathrm{W}$ & 0.668 & 14.411 & 3.873 \\
\hline $\mathrm{D}, \mathrm{GPD}, \mathrm{W}, \mathrm{HDI}$ & 0.68 & 14.945 & 4.407 \\
\hline GPD, W, F, HDI & 0.677 & 15.387 & 4.849 \\
\hline D, GPD, F, HDI & 0.677 & 15.453 & 4.916 \\
\hline $\mathrm{D}, \mathrm{GPD}, \mathrm{W}, \mathrm{F}$ & 0.673 & 16.152 & 5.615 \\
\hline $\mathrm{D}, \mathrm{GPD}, \mathrm{W}, \mathrm{F}, \mathrm{HDI}$ & 0.68 & 17.562 & 7.024 \\
\hline HDI & 0.104 & 63.213 & 52.676 \\
\hline $\mathrm{D}, \mathrm{HDI}$ & 0.109 & 65.23 & 54.693 \\
\hline W, HDI & 0.106 & 65.42 & 54.882 \\
\hline F, HDI & 0.104 & 65.548 & 55.01 \\
\hline F & 0.035 & 67.213 & 56.675 \\
\hline $\mathrm{D}, \mathrm{W}, \mathrm{F}$ & 0.116 & 67.233 & 56.696 \\
\hline $\mathrm{D}, \mathrm{F}, \mathrm{HDI}$ & 0.109 & 67.653 & 57.116 \\
\hline W, F, HDI & 0.106 & 67.85 & 57.312 \\
\hline W & 0.018 & 68.166 & 57.629 \\
\hline $\mathrm{W}, \mathrm{F}$ & 0.048 & 68.832 & 58.294 \\
\hline $\mathrm{D}$ & $<.001$ & 69.136 & 58.599 \\
\hline $\mathrm{D}, \mathrm{F}$ & 0.035 & 69.546 & 59.009 \\
\hline $\mathrm{D}, \mathrm{W}, \mathrm{F}, \mathrm{HDI}$ & 0.117 & 69.751 & 59.213 \\
\hline $\mathrm{D}, \mathrm{W}$ & 0.024 & 70.162 & 59.624 \\
\hline $\mathrm{D}, \mathrm{W}, \mathrm{F}$ & 0.05 & 71.119 & 60.581 \\
\hline
\end{tabular}

Table 2. Selected models showing each variable used, the importance, the standardized regression coefficient considering all models, and the standardized regression coefficient considering only the best model. The variables are population density (inhabitants $/ \mathrm{km}^{2}$ ) (D); GDP (millions of US dollars), water availability (W), fertilizer consumption (F) and HDI.

\begin{tabular}{ccc}
\hline Variable & Importance & Coefficient \\
\hline D & 0.29 & -0.05 \\
GPD & 1 & 0.47 \\
W & 0.301 & 0.029 \\
F & 0.28 & -0.035 \\
HDI & 0.358 & -0.27 \\
\hline
\end{tabular}




\section{DISCUSSION}

Studies with Chl-a showed a growing over the years analyzed in the study, and this variable indicative of living in aquatic and terrestrial environments. The search domain knowledge in diverse habitats makes it necessary mastery of certain indicator variables immediately Chl-a is used as an indicator of biomass aquatics, vegetation.

These works were published mostly by multidisciplinary journals demonstrating that research with this variable are used in a multidisciplinary approach for the Chl-a is subject to various changes in the environment. Another important aspect of this study is that of Chl-a to be used as the main variable in research descriptive of the place are mostly regional and marine environments. Leading the way screening study concerning Chl-a as a variable of study.

This survey of the state of knowledge about Chl-a allowed us to ordinate the groups of information and results, to provide an overall view of investigations on this subject. Assessments of the state of development of a certain area may help to improve and develop new postulates, concepts and paradigms. Our results showed that over 21 years, the number of publications on Chl-a has continued to grow, a pattern also found in other scientometric studies, for instance on phytoplankton (CARNEIRO et al., 2008), macrophytes (PADIAL et al., 2008), population ecology (LIMA-RIBEIRO et al., 2007), genetic studies using flow cytometry (QUIXABEIRA et al., 2010), niche models used in invasive species (BARBOSA et al., 2012) and global climate change (NABOUT et al., 2012).

This increase in the number of publications on Chl-a can be related to the use of microorganisms in the search for field techniques in biotechnology (SHEEHAN et al., 1998; GROBBELAAR, 2010), laboratory research and the reaction kinetics (PRUZINKÁ et al., 2003; WANG et al., 2011), evaluation of the physicochemical properties of Chl-a under various treatment conditions (MAXWELL et al., 2003 ; CARBONERA et al., 2012; FERNANDEZJARAMILLO et al., 2012), its use in medicine (BRITTON, 1995; SCHOEFS, 2002), concern for sustainable use of the environment where this is a tracking variable (THOMAS et al., 2001; AFFONSO et al., 2011; LUGOLI et al., 2012), and also characterization of Chl-a optical properties for use in hyperspectral optical sensors of satellites, which facilitate gathering data on photosynthesis on temporal and spatial scales (NOVOA et al., 2011; GURLIN et al., 2011).
Studies on Chl-a are mostly descriptive $(53 \%)$, as this variable provides an indirect measurement of phytoplankton biomass, the NDVI (Normalized Difference Vegetation Index) of a vegetated area, and water-quality parameters in limnology. All these studies are empirical in nature, where performing field research is essential (WANG et al., 2003; GARMENDIA et al., 2011). In many areas of science, a high proportion of the papers are descriptive (LIMA-RIBEIRO et al., 2007; CARNEIRO et al., 2008), especially in areas with a well-defined body of theory that has been advanced in the development of new techniques, as is the case for Chl-a.

More part of chl-a studies were developed in the marine environment. Several marine studies use Chl-a to estimate the phytoplankton biomass (e.g. GOWER; KING, 2008). Estimates of marine phytoplankton biomass have many applications, including aquaculture management (WILD-ALLEN et al., 2011), monitoring using satellite imagery (NOVOA et al., 2011; GURLIN et al., 2011) and forecasting algal blooms (SHEN et al., 2012). Chl-a is also a useful explanatory variable in continental waters, where it is used as a parameter for monitoring, quantification of photosynthetic species, quality assessment, and detection of water pollution.

Authors from the USA contributed most papers. The predominance of authors from this country has been reported in several studies (FAZEY et al., 2005; CARNEIRO et al., 2008; NABOUT et al., 2010). Part of the reason for this must be the greater investment in infrastructure and research (MUGNAINI et al., 2004; JAPPE, 2007). However, a high proportion of studies on Chl-a have been conducted in China. These results indicate a partnership between countries (for example China and the USA), where although most articles are by authors from the USA, the studies were conducted in China, or possibly American authors worked in China along with Chinese authors. Despite the importance of partnerships for increasing scientific output, this study showed that the GDP is the main variable that explained the variations in the country of the study, since this indicator expresses the sum of the wealth generated by all the various sectors. These sectors in turn are motivated by technological development and are based on scientific development. Other studies have shown a similar positive relationship between the two variables (GDP and number of papers), e.g., that of Nabout et al. (2010) on the global literature on fiddler crabs (genus $U c a$ ).

Finally, the present study traced the state of knowledge on Chl-a on a global scale. In spite of the 
increasing number of articles, several research areas and geographical regions remain relatively unexplored, such as experimental studies and studies in continental aquatic environments. Studies in freshwater ecosystems aid in determining the quality and multi-use availability of a water body. Experimental studies are important to assess the importance of Chl-a in specific conditions, such as global climate change (BICUDO; BICUDO, 2008; KALAJI et al., 2011). Because of the importance of this environmental variable, we recommend studies on the impact of global climate change on Chl-a, because of the relative paucity of studies on climate change in aquatic environments (NABOUT et al., 2012).

\section{ACKNOWLEDGEMENTS}

This work was developed with funds from $\mathrm{CNPq} / \mathrm{MCT} / \mathrm{CAPES}$ and FAPEG (project \# 563834/2010-2) and FAPEG (process 201210267001071) partially supported by CAPES (Auxpe 2036/2013). SMLOM received scholarships by FAPEG and SEDUC, MTRA received scholarships by CAPES, PPB and KBM received scholarships by CNPq (2012) and CAPES (20132014). CSTA and HFC were supported by University Research and Scientific Production Support Program (PROBIP/UEG). JCN was supported by CNPq productivity fellowships.

RESUMO: A clorofila é um pigmento verde, comum em todas as células fotossintéticas de organismos autotróficos, de ambientes aquáticos ou terrestres. As técnicas mais utilizadas para quantificar esse pigmento são a fluorescência, a espectrofotometria de UV, a cromatografia HPLC e o uso de sensores remotos. Assim, a determinação do pigmento fotossintético chlorofila-a (Chl-a), tem sido utilizada amplamente em diversas áreas da ciência. Portanto, o objetivo deste trabalho foi investigar o estado da arte da literatura científica para o pigmento fotossintetizante clorofila-a, determinando os países de estudo, os fatores socioeconômicos- ambiental que estão ligados ao estudo de clorofila -a, abordagens utilizadas, e ainda, os ambientes estudados, a escala geográfica e as revistas. Para obter tais informações realizou-se um estudo cienciométrico, a partir da base de dados Scopus, numa escala temporal de 21 anos (entre 1990 e 2011). Os padrões encontrados para as pesquisas com Chl-a são o aumento temporal de publicações ( $\mathrm{r}=0.84$ and $P<$ 0.001 ), a diversidade de revistas que publicaram estudos sobre o assunto (160 revistas), maior número de publicações com caráter multidisciplinar, predomínio de estudos com abordagens descritivas realizados em ambientes aquáticos e marinhos e estudos em escala geográfica regional. A China foi o país mais estudado com $21,64 \%$ do total de artigos publicados, e os estadunidenses lideraram com o maior número de publicações sobre este assunto (19,52\% do total de artigos publicados). Utilizando o critério de seleção de modelos de Akaike observou-se que as publicações são impulsionadas pelo fator socioeconômico PIB. Este estudo demonstrou o uso multidisciplinar da Chl-a e pode indicar algumas direções para novos estudos com esse pigmento.

PALAVRAS-CHAVE: Pigmento Fotossintetizante. Cienciometria. Água. Biomassa Fitoplanctônica.

\section{REFERENCES}

AFFONSO, A. G., QUEIROZ, H. L.; NOVO, E. M. L. M. Limnological characterization of floodplain lakes in Mamirauá Sustainable Development Reserve, Central Amazon (Amazonas State, Brazil). Acta Limnologica Brasiliensia, Rio Claro, v. 23, n. 1, p. 95-108, 2011.

BARBOSA, F. G.; SCHNECK, F.; MELO, A. S. Use of ecological niche models to predict the distribution of invasive species: a scientometric analysis. Brazilian Journal of Biology, São Carlos, v. 72, p. 821-829, 2012. http://dx.doi.org/10.1590/S1519-69842012000500007

BICUDO, C. E. M.; BICUDO, D. Mudanças Climáticas Globais: Efeitos sobre as Águas Continentais Superficiais. In: Biologia \& Mudanças Climáticas no Brasil. M. S. Buckeridge (org.) Rima Editora. São Carlos:2008. p. 151-165.

BINI, L. M.; DINIZ-FILHO, J. A. F.; CARVALHO, P.; PINTO, M. P.; RANGEL, T. F. L. V. B. Lomborg and the litany of biodiversity crisis: what the peer review literature says. Conservation Biology, Germantown, v. 20, p. 1-6, 2005. http://dx.doi.org/10.1111/j.1523-1739.2005.00155.x 
BJORN, L. O.; PAPAGEORGIOU, G. C.; BLANKENSHIP, R.; GOVINDJEE. A viewpoint: why chlorophyll a? Photosynthesis Research, Netherlands, v. 99, p. 85-98, 2009. http://dx.doi.org/10.1007/s11120-008-9395-x

BRITTON, G. UV Visible spectroscopy. In: BRITTON, G. et al. (Eds). Carotenoids, spectroscopy.

Switzerland: Birkhauser, Basel, 1995. p. 13-62.

BURNHAM, K. P.; ANDERSON, D. R. Model selection and multimodel inference: a practical information theoretic approach. New York: Springer. 2002.488p.

CARBONERA, D.; GEROTTO, C.; POSOCCO, B.; GIACOMETTI, G. M.; MOROSINOTTO, T. NPQ Activation reduces chlorophyll triplet state formation in the moss Physcomitrella patens. Biochimica et Biophysica Acta (BBA) - Bioenergetics, Cambrige, v. 1817, p. 1608-1615,2012.

http://dx.doi.org/10.1016/j.bbabio.2012.05.007

CARNEIRO, F. M.; NABOUT, J. C.; BINI, L. M. Trends in the scientific literature on phytoplankton. Limnology, Japan, v. 9, p. 153-158, 2008. http://dx.doi.org/10.1007/s10201-008-0242-8

FAZEY, I.; FISCHER, J.; LINDENMAYER, D.B. What do conservation biologists publish? Biological Conservation, Washigton, v. 124, n. 1, p. 63-73, 2005.

FERREIRA, R. B.; BORGES NETO, A. C.; NABOUT, J. C.; JESUS, F. F.; CAETANO, J. M.; TEIXEIRA, I. R. Tendências na literatura científica global sobre o Biodiesel: uma análise cienciométrica. Bioscience Journal (UFU. Impresso), Uberlândia, v. 30, p. 547-554, 2014.

FERNANDEZ-JARAMILLO, A. A.; DUARTE-GALVAN, C.; CONTRERAS-MEDINA, L. M.; TORRESPACHECO, I.; ROMERO-TRONCOSO, R. J.; GUEVARA-GONZALEZ, R. G.; MILLAN-ALMARAZ, J. R. Instrumentation in Developing Chlorophyll Fluorescence Biosensing: A review. Sensors, Switzerland, v. 12, p. 11853-11869, 2012. http://dx.doi.org/10.3390/s120911853

FMI. Fundo Monetário Internacional. Disponível em http: <//www.imf.org.com>. Acesso em: 8 setembro de 2012.

GARMENDIA, M.; REVILLA, M.; BALD, J.; FRANCO, J.; MARTINEZ, A. L.; ORIVE, S. S.; VALENCIA, V.; BORJA, A. Phytoplankton communities and biomass size structure (fractionated chlorophyll "a"), along trophic gradients of the Basque coast (northern Spain). Biogeochemistry, Netherlands, v. 106, p. 243-263, 2011. http://dx.doi.org/10.1007/s10533-010-9445-2

GOWER, J.; KING, S. Global monitoring of plankton blooms using MERIS MCI. International Journal of Remote Sensing, Terre Haute, v. 29, p. 6209-6216, 2008. http://dx.doi.org/10.1080/01431160802178110

GROBBELAAR, J. U. Microalgal biomass production: challenges and realities. Photosynthesis Research, Nerthelands, v. 106, p. 135-144, 2010.

GURLIN, D.; GITELSON, A. A.; MOSES, W. J. Remote estimation of chl- $a$ concentration in turbid productive waters - Return to a simple two-band NIR-red model? Remote Sensing of Environment, Flórida, v. 115, p. 3479-3490, 2011. http://dx.doi.org/10.1016/j.rse.2011.08.011

HAWES, I.; LUND-HANSEN, L. C.; SORREL, B. K.; NIELSEN, M. H.; BORZÁK, R.; BUSS, I. Photobiology of sea ice algae during initial spring growth in Kangerlussuaq, West Greenland: insights from imaging variable chlorophyll fluorescence of ice cores. Photosynthesis Research, Nerthelands,v. 112, n. 2, p. 103-115, 2012.

HUO, S.; ZAN, F.; CHEN, Q.; XI, B.; SU, J.; JI, D.; XU, Q. Determining reference conditions for nutrients, chlorophyll a and Secchi depth in Yungui Plateau ecoregion lakes, China. Water and Environment Journal, Reino Unido v. 26, p. 324-334, 2012. 
JAPPE, A. Explaining international collaboration in global environmental change research. Scientometrics, Netherlands, v. 71, n. 3, p. 367-390, 2007. http://dx.doi.org/10.1007/s11192-007-1676-1

KALAJI, H. M.; BOSA, K.; KOSCIELNIAK, J.; HOSSAIN, Z. Chlorophyll a Fluorescence . A Useful Tool for the Early Detection of Temperature Stress in Spring Barley (Hordeum vulgare L.). OMICS: A Journal of Integrative Biology, New Rochelle, v. 15, p. 925-934, 2011.

KOZIOL, A. G.; BORZA, T.; ISHIDA, K. I.; KEELING, P.; LEE, R. W.; DURNFORD, D. G. Tracing the evolution of the light-harvesting antennae in chlorophyll a/b-containing organisms. Plant Physiology, Rockville, v. 143, p. 1802-1816, 2007. http://dx.doi.org/10.1104/pp.106.092536

KRAUSE, G. H.; WINTER, K. B.; JAHNS, P.; GARCIA, M.; ARANDA, J.; VIRGO, A. High-temperature tolerance of a tropical tree, Ficus insipida: methodological reassessment and climate change considerations. Functional Plant Biology, Austrália, v. 3, p. 890-900, 2010. http://dx.doi.org/10.1071/FP10034

LIMA-RIBEIRO, M. S.; NABOUT, J. C.; PINTO, M. P.; MOURA, I. O; MELO, T. L; COSTA, S. S.; RANGEL, T. L. V. V. B. Análise cienciométrica em ecologia de populações: importância e tendências dos últimos 60 anos. Acta Scientiarum: Biological Sciences, Maringá, v. 29, p. 39-47, 2007.

LLOYD, S. W.; TUCKER, C. S. Comparison of Three Solvent Systems for Extraction of Chlorophyll $a$ from Fish Pond Phytoplankton Communities. Journal of the world aquaculture society, Baton Rouge, v. 19, p. 3640, 1988.

LUGOLI, F.; GARMENDIA, M.; LEHTINEN,S.; KAUPPILA, P.; MONCHEVA, S.; REVILLA, M.; ROSELLI, L.; SLABAKOVA, N.; VALENCIA,V.; DROMPH, K.M.; BASSET, A. Application of a new multi-metric phytoplankton index to the assessment of ecological status in marine and transitional waters. Ecological Indicators, Netherlands, v. 23, p. 338-355, 2012. http://dx.doi.org/10.1016/j.ecolind.2012.03.030

MACIAS-CHAPULA, C. A. O papel da informetria e da cienciometria e sua perspectiva nacional e internacional. Ciência da Informação, Brasília, v. 27, n. 2, p. 134-140, 1998. http://dx.doi.org/10.1590/S010019651998000200005

MAXWELL, B. B.; ANDERSON, C. R.; POOLE, D. S.; KAY, S. A.; CHORY, J. HY5, Circadian ClockAssociated 1, and a cis-Element, DET1 Dark Response Element, Mediate DET1 Regulation of Chlorophyll a/bBinding Protein 2 Expression. Plant physiology, Rockville, v. 133, p. 1565-1577, 2003.

MELO, A. S.; BINI, L. M.; CARVALHO, P. Brazilian articles in international journals on Limnology. Scientometrics, Netherlands, v. 67, n. 2, p. 187- 199, 2006. http://dx.doi.org/10.1007/s11192-006-0093-1

MUGNAINI, R.; JANUZZI, P. M.; QUONIAM, L. Indicadores bibliométricos da produção científica brasileira: uma análise a partir da base Pascal. Ciência da Informação, Brasília, v. 33, n. 2, p. 123-131, 2004. http://dx.doi.org/10.1590/S0100-19652004000200013

NABOUT, J. C.; BINI, L. M.; DINIZ-FILHO, J. A. F. Global literature of fiddler crabs, genus Uca (Decapoda, Ocypodidae): trends and future directions. Iheringia. Série Zoologia , Porto Alegre, v. 100, p. 463-468, 2010. http://dx.doi.org/10.1590/S0073-47212010000400019

NABOUT, J. C.; CARVALHO, P.; PRADO, M. U.; BORGES, P. P.; MACHADO, K. B.; HADDAD, K. B.; MICHELAN, T. S.; CUNHA, H. F.; SOARES, T. N. Trends and Biases in Global Climate Change Literature. Natureza \& Conservação, Goiânia, v. 10, p. 45-51, 2012. http://dx.doi.org/10.4322/natcon.2012.008

NOVOA, S.; CHUST, G.; VALENCIA, V.; FROIDEFOND, J. M.; MORICHON, D. Estimation of chlorophyll- $a$ concentration in watersover the continental shelf of the Bay of Biscay: acomparison of remote sensing algorithms. International Journal of Remote Sensing, Terre Haute, v. 32, p. 8349-8371, 2011. http://dx.doi.org/10.1080/01431161.2010.540588 
PADIAL, A. A.; BINI, L. M.; THOMAZ, S. M. The study of aquatic macrophytes in Neotropics: a scientometrical view of the main trends and gaps. Brazilian Journal of Biology, São Carlos v. 68, p. 10511059, 2008. http://dx.doi.org/10.1590/S1519-69842008000500012

PELLETIER, P. J.; CAVENTOU, J. B. Sur la matiere verte des feuilles. Annales de chimie et de physique, Paris, v. 9, p. 194-196, 1818.

PEREZ, E. B.; PINA, I. C.; RODRIGUEZ, L. P. Kinetic model for growth of Phaeodactylum tricornutum in intensive culture photobioreactor. Biochemical Engineering Journal, Illinois,v. 40, n. 3, p. 520-525, 2008. http://dx.doi.org/10.1016/j.bej.2008.02.007

PINTO, M. P.; BINI, L. M.; DINIZ-FILHO J. A. F. Quantitative analysis of the influence of a new ecological paradigm: spatial autocorrelation (Análise quantitativa da influência de um novo paradigma ecológico: autocorrelação espacial). Acta Scientiarum: Biological Sciences, Maringá, v. 25, n. 1, p. 137-143, 2003.

PNUD. Atlas do Desenvolvimento Humano no Brasil. Disponível em: <http://www.pnud. org.br/ atlas/>. Acesso em: 5 de setembro de 2012.

PRUZINSKA, A.; TANNER, G.; ANDERS, I.; ROCA, M.; HORTENSTEINER, S. Chlorophyll breakdown: Pheophorbide a oxygenase is a rieke-type iron- sulfur protein, encoded by the accelerated cell death 1 gene.

Plant Biology, Netherlands, v. 100, n. 25, p. 123-128, 2003.

QUIXABEIRA, V. B. L.; NABOUT, J. C.; RODRIGUES, F. M. Trends in genetic literature with the use of flow cytometry. Cytometry Part A, Malden, v. 77 a, p. 207-210, 2010.

RANGEL, T. F. L. V. B.; DINIZ, J. A. F.; BINI, L. M. SAM: a comprehensive application for Spatial Analysis in Macroecology. Ecography, Sweden, v. 31, p. 46-50, 2010. http://dx.doi.org/10.1111/j.16000587.2009.06299.x

RIANO, B.; HERNANDEZ, D.; GARCIA-GONZALEZ, M. Microalgal-based systems for wastewater treatment: Effect of applied organic and nutrient loading rate on biomass composition. Ecological Engineering, Flórida, v. 49, p. 112-117, 2012. http://dx.doi.org/10.1016/j.ecoleng.2012.08.021

SCHOEFS, B. Chlorophyll and carotenoid analysis in food products. Properties of the pigments and methods of analysis. Trends in Food Science \& Technology, Wageningen, v. 13, p. 361-371, 2002.

SHEEHAN, J.; DUNAHAY, T.; BENEMANN, J.; ROESSLER, P. A Look Back at the US Department of Energy's Aquatic Species Program: biodiesel from algae. US Department of Energy's, Office of Fuels development. NREL/TP-580-24190., Colorado,1998. 328 p.

SHEN, L.; HUIPING, X.; GUO, X. Satellite Remote Sensing of Harmful Algal Blooms (HABs) and a Potential Synthesized Framework. Sensors, Switzerland, v. 12, p. 7778-7803, 2012.

http://dx.doi.org/10.3390/s120607778

SKJANES, K.; LINDBLAD, P.; MULLER, J. BiOCO2 - A multidisciplinary, biological approach using solar energy to capture $\mathrm{CO} 2$ while producing H-2 and high value products. Biomolecular Engineering, Poland, v. 24, p. 405-413, 2007. http://dx.doi.org/10.1016/j.bioeng.2007.06.002

STANHILL G. The growth of climate change science: a scientometric study. Climatic Change, Netherlands, v. 48, p. 515-524, 2001. http://dx.doi.org/10.1023/A:1010721600896

SUBASHCHANDRABOSE, SR., RAMAKRISHNAN, B., MEGHARAJ, M., VENKATESWARLU, K.; NAIDU, R. Consortia of cyanobacteria/microalgae and bacteria: Biotechnological potential. Biotechnology Advances, Israel, v. 29, p. 896-907, 2011. http://dx.doi.org/10.1016/j.biotechadv.2011.07.009 
THOMAS, H.; OUGHAM, H.; HORTENSTEINER, S. Recent advances in the cell biology of chlorophyll catabolism. Advances in Botanical Research, France, v. 35, p. 1-52, 2001. http://dx.doi.org/10.1016/S00652296(01)35003-6

VANTI, N. A. P. Da bibliometria à webometria: uma exploração conceitual dos mecanismos utilizados para medir o registro da informação e a difusão do conhecimento. Ciência da Informação, Brasília, v. 31, n. 2, p. 152-162, 2002. http://dx.doi.org/10.1590/S0100-19652002000200016

WANG, J. J.; LI, J. Z.; LI, F. G. The region selective Synthesis of bromochlorins related to chlorophyll-a from methyl pheophorbide-a. Journal of the Iranian Chemical Society, Germany, v. 8, n. 4, p. 1139-1145, 2011. http://dx.doi.org/10.1007/BF03246572

WANG, Z. X.; LIU, C.; HUETE, A. From AVHRR-NDVI to MODIS-EVI: advances in vegetation index research. Acta Ecologica Sinica, China, v. 23, n. 5,p. 979-988,2003.

WETZEL, R. G. Limnology: Lake and River Ecosystems. Academic Press, San Diego.2001, 1006 p.

WILD-ALLEN, K.; THOMPSON, P. A.; VOLKMAN, J. K.; PARSLOW, J. Use of a coastal biogeochemical model to select environmental monitoring. Journal of Marine Systems, Germany, v. 88, p. 120-127, 2011. http://dx.doi.org/10.1016/j.jmarsys.2011.02.017

ZHANG , M. P.; ZHANG, C. J.; YU, G. H.; JIANG, Y. Z.; STRASSER, R. J.; YUAN, Z. Y.;YANG, X. S.; CHEN, G. X. Changes in chloroplast ultrastructure, fatty acid components of thylakoid membrane and chlorophyll a fluorescence transient in flag leaves of a super-high-yield hybrid rice and its parents during the reproductive stage. Journal Plant physiology, Ontário, v. 167, p. 277-285, 2010. 